\title{
The effect of dietary fibre fractions from different cereals and microbial enzyme supplementation on performance, ileal viscosity and short-chain fatty acid concentrations in the caeca of broiler chickens*
}

\author{
D. Józefiak ${ }^{1,3}$, A. Rutkowski ${ }^{1}$, M. Frątczak ${ }^{1}$ and D. Boros ${ }^{2}$ \\ ${ }^{1}$ August Cieszkowski Agricultural University, \\ Department of Animal Nutrition and Feed Management \\ Wotyńska 33, 60-637 Poznań, Poland \\ ${ }^{2}$ Institute of Plant Breeding and Acclimatization, \\ Laboratory of Nutritional Evaluation of Plant Material \\ Radzików, 05-870 Błonie, Poland
}

(Received 23 September 2003; revised version 20 May 2004; accepted 16 June 2004)

\begin{abstract}
A five-week-long experiment was performed on 960 one-day-old Cobb 500 cockerels divided randomly into ten experimental groups of 12 cages (replicates) of 8 birds each. The objective of the experiment was to estimate the effect of non-starch polysaccharides (NSP) derived from various cereals and addition of microbial enzyme preparations on growth performance, ileal viscosity, liver weight and concentration of short-chain fatty acids in broiler chicken caeca. Barley and oats, hulless barley, naked oats, and rye constituted the majority of diets. Diets were non-supplemented or supplemented with a commercial enzyme preparation. Enzyme preparations significantly improved feed conversion ratio and body weight gains $(\mathrm{P}<0.05)$ only in groups fed diets based on naked oats and rye. In all groups, enzyme supplementation decreased intestinal viscosity and increased the concentration of acetate and total short-chain fatty acids in caecal digesta with the exception of the group fed the diet with naked oats.

The results indicate that not total dietary fibre content, but the type of dietary NSP, as well as microbial enzyme supplementation, may influence the intestinal viscosity and performance of broiler chickens.
\end{abstract}

KEY WORDS: broiler chicken, cereals, non-starch polysaccharides, microbial enzymes, caeca, short-chain fatty acids

\footnotetext{
* Supported by the State Committee for Scientific Research, Grant No. 3 PO6Z04425

${ }^{3}$ Corresponding author: e-mail: damjo@owl.au.poznan.pl
} 


\section{INTRODUCTION}

Starch serves as a major source of energy in poultry diets. The predominant monosaccharides in poultry diets are glucose and fructose, while the predominant disaccharide is sucrose. Starch, as well as simple sugars, is well digested, while the digestion of non-starch polysaccharides (NSP) tends to be more variable, it is generally very low due to the lack of digestive enzymes able to hydrolyse them. Moreover, in the poultry gastrointestinal tract (GIT) soluble NSP's have shown a tendency to create a viscous environment within the intestinal lumen, which further decreases the digestibility of NSP's and other nutrients (Steenfeldt et al., 1998; Jamroz et al., 2002). In the GIT of poultry NSP can be hydrolysed to a small extent by enzymes produced by the caecal microflora and to a high degree by added enzymes (Jamroz et al., 1998, 2002; Choct et al., 1999).

Some microbial enzymes (i.e. xylanase, ß-glucanase) reduce ileal viscosity, thus enhancing nutrient digestion and absorption. However, there is little data about their role in the distal parts of the poultry GIT, especially when different cereals are used in diets.

Many researchers have speculated about the role of the caeca in birds, including broiler chickens. In general, there has been interest in finding a relationship between the size of this organ and its function in the digestion of fibrous diets as well as its role in water absorption (Józefiak et al., 2004). Today, most authors agree that caeca are the primary fermentative chambers in the poultry GIT, where some undigested carbohydrates are transformed into short-chain fatty acids (SCFA) and gasses (Józefiak et al., 2004). Similarly as in ruminants or other non-ruminants, the end products of fermentation in chicken caeca may contribute some amount of energy to the host bird and play an important role in regulating caecal microflora populations (Jamroz et al., 2002; Józefiak et al., 2004). Thus, it is suggested that enhancing the fermentation processes in broiler chicken caeca may lead to more promising results than previously thought. However, data about SCFA concentrations in the chicken caeca after enzyme supplementation are contradictory (Choct et al., 1999; Lázaro et al., 2003).

The objective of the experiment was to study the influence of the dietary fibre of different cereals and microbial enzyme supplementation on the performance of broiler chickens as well as on fermentation processes in the caeca.

\section{MATERIAL AND METHODS}

\section{Animals and diets}

The experiment was performed on 960 one-day-old Cobb 500 cockerels divided randomly into 10 groups, each containing 12 cages (replicates), 8 birds 
per replicate. Ten isoproteinous and isoenergetic diets, based on barley, oats, hulless barley, naked oats, or rye were prepared, each as starter and grower types (Table 1). Diets with the first four cereals were prepared with or without $1 \mathrm{~g} / \mathrm{kg}$ of the enzyme preparation, Avizyme ${ }^{\circledR} 1100$ produced by Danisco (UK) (containing $100 \mathrm{U} / \mathrm{g}$ endo $1,3(4)$ - $\beta$-glucanase; $300 \mathrm{U} / \mathrm{g}$ endo $1,4-\beta$-xylanase and $800 \mathrm{U} / \mathrm{g}$ protease). The rye diet was unsupplemented or supplemented with Avizyme ${ }^{\circledR} 1300$ produced by Danisco (UK) (containing $2500 \mathrm{U} / \mathrm{g}$ endo 1,4- $\beta$-xylanase and $800 \mathrm{U} / \mathrm{g}$ protease according to producer). Soyabean protein concentrate (HP 300; Hammlet Protein, Denmark) was used as a protein source. Apart from salinomycin, an ionophore antibiotic used to control coccidiosis, the diets did not contain antibiotic growth promoters (Table 1). Chickens were fed mash diets ad libitum, Starter from the 1st to 14th day of life and Grower from the 15th to the 35th day of life. Feed intake and body weight

TABLE 1

Composition ( $\mathrm{g} \mathrm{kg}^{-1}$ dry matter) and nutritional value of diets in the starter and grower period

\begin{tabular}{|c|c|c|c|c|c|c|c|c|c|c|}
\hline \multirow[b]{2}{*}{ Ingredients } & \multicolumn{5}{|c|}{ Starter } & \multicolumn{5}{|c|}{ Grower } \\
\hline & barley & $\begin{array}{l}\text { hulless } \\
\text { barley }\end{array}$ & oat & $\begin{array}{c}\text { hulless } \\
\text { oat }\end{array}$ & rye & barley & $\begin{array}{l}\text { hulless } \\
\text { barley }\end{array}$ & oat & $\begin{array}{c}\text { hulless } \\
\text { oat }\end{array}$ & rye \\
\hline Barley & 632.0 & - & - & - & - & 674.0 & - & - & - & - \\
\hline Hulless barley & - & 675.0 & - & - & - & - & 714.0 & - & - & - \\
\hline Oat & - & - & 610.3 & - & - & - & - & 644.0 & - & - \\
\hline Hulless oat & - & - & - & 793.0 & - & - & - & - & 850.0 & - \\
\hline Rye & - & - & - & - & 581.0 & - & - & - & - & 613.0 \\
\hline HP $300^{1}$ & 234.0 & 206.0 & 236.5 & 140 & 274 & 188.2 & 160.0 & 192.0 & 87.8 & 230.5 \\
\hline Rapeseed oil & 72.0 & 54.0 & 94.0 & 1.5 & 88.5 & 82.0 & 67.0 & 112.0 & 5.0 & 105.0 \\
\hline Dicalcium phoshpate & 20.0 & 20.5 & 21.0 & 22.0 & 22.0 & 19.0 & 20.5 & 20.0 & 17.5 & 22.0 \\
\hline Limestone & 6.0 & 5.5 & 5.2 & 4.5 & 4.0 & 5.3 & 4.5 & 4.3 & 6.3 & 3.0 \\
\hline DL-methionine $20 \%$ & 11.0 & 11.0 & 11.0 & 10.0 & 10.5 & 8.5 & 8.5 & 8.0 & 7.8 & 8.0 \\
\hline L-lysine $20 \%$ & 11.0 & 14.0 & 8.0 & 15.0 & 6.0 & 10.0 & 12.5 & 6.7 & 12.6 & 5.5 \\
\hline Constant components ${ }^{2}$ & 13.0 & 13.0 & 13.0 & 13.0 & 13.0 & 13.0 & 13.0 & 13.0 & 13.0 & 13.0 \\
\hline \multicolumn{11}{|l|}{ Calculated } \\
\hline $\mathrm{ME}$ in $\mathrm{MJ} / \mathrm{kg}$ & 12.5 & 12.5 & 12.5 & 12.5 & 12.5 & 13.0 & 13.0 & 13.0 & 13.0 & 13.0 \\
\hline crude protein & 206.0 & 206.0 & 206.0 & 206.0 & 206.0 & 185.0 & 185.0 & 185.0 & 185.0 & 185.0 \\
\hline lysine & 12.7 & 12.7 & 12.7 & 12.7 & 12.7 & 10.6 & 10.6 & 10.6 & 10.6 & 10.6 \\
\hline methionine & 5.3 & 5.3 & 5.3 & 5.3 & 5.3 & 4.5 & 4.5 & 4.5 & 4.5 & 4.5 \\
\hline $\mathrm{Ca}$ & 9.8 & 9.8 & 9.8 & 9.8 & 9.8 & 9.4 & 9.4 & 9.4 & 9.4 & 9.4 \\
\hline
\end{tabular}

${ }^{1}$ unsupplemented ; supplemented diets contained $1 \mathrm{~g}$ of Avizyme 1100 or Avizyme 1300 (to rye diet only) which substituted $1 \mathrm{~g}$ of respective cereal

${ }^{2}$ soyabean meal protein concentrate $\left(530 \mathrm{~g}\right.$ crude protein per $\mathrm{kg}^{-1}$ dry matter)

${ }^{3}$ supplying per $\mathrm{kg}$ of diet: $\mathrm{NaCl} 3 \mathrm{~g}$; $\mathrm{NaHCO}_{3} 1 \mathrm{~g}$; retinol (retinyl acetate) $5 \mathrm{mg}$; cholecalciferol 0.09 mg; vit. E (dl- $\alpha$-tocopheryl acetate) $42 \mathrm{mg}$; menadione $3.5 \mathrm{mg}$; thiamin $1.4 \mathrm{mg}$; riboflavin $11.2 \mathrm{mg}$; pyridoxine $4.2 \mathrm{mg}$; d-pantothenic acid $12 \mathrm{mg}$; niacin $52 \mathrm{mg}$; folic acid $2.1 \mathrm{mg}$; biotin $28 \mu \mathrm{g}$; BHT 140 $\mathrm{mg} ; \mathrm{FeSO}_{4} \times 7 \mathrm{H}_{2} \mathrm{O} 112 \mathrm{mg} ; \mathrm{ZnO} 112 \mathrm{mg} ; \mathrm{MnO} 140 \mathrm{mg}$; salinomycin $50 \mathrm{ppm}$ 
were measured at weekly intervals, average feed conversion ratio (FCR) and body weight gain (BWG) were calculated in each replicate. At the end of the experiment, ten chickens from each treatment were killed by cervical dislocation. After dissection, their livers were rinsed in distilled water and weighed, digesta from the jejunum was collected for viscosity measurements, while digesta from both caeca were collected into sterile plastic tubes and kept at $-20^{\circ} \mathrm{C}$ for further SCFA analyses.

\section{Analytical methods}

The contents of dry matter, crude protein, crude fat and starch were determined using AOAC (1990) procedures. Total and insoluble NSP and arabinoxylans (Table 3) were determined after acid hydrolysis as alditol acetates by gas chromatography (HP 5890) as described by Englyst and Cummings (1984). Soluble NSP and arabinoxylans were calculated from the differences between the total and insoluble counterparts. The total amount of dietary fibre was calculated as the sum of the total NSP and Klason lignin (not shown). The in vitro viscosity of water (WEV) and acid extracts (AEV) was estimated according to Boros et al. (1993). Ground cereals were mixed with distilled water or $0.1 \mathrm{M} \mathrm{HCl} / \mathrm{KCl}$ buffer $(1: 5 \mathrm{w} / \mathrm{w})$ and extracted for $1 \mathrm{~h}$ at $30^{\circ} \mathrm{C}$, centrifuged for $8 \mathrm{~min}$ at $8000 \mathrm{rpm}$ and the viscosity of the supernatants was measured at a rate of 12/s using a Brookifield Digital DV-II+ cone/plate viscometer (Brookfield Engineering Laboratories, Stoughton, USA). Approximately $3 \mathrm{~g}$ of digesta from the jejunum were centrifuged for $8 \mathrm{~min}$ at 8000 $\mathrm{rpm}$ for viscosity measurement. The viscosity of supernatants was measured at the rate of 30/s using a Brookifield Digital DV-II+ cone/plate viscometer as described by Steenfeldt et al. (1998). The concentrations of short-chain fatty acids (SCFA) in the caecal contents were determined using gas chromatography (Varian CP 3380) under conditions described by Jensen et al. (1995).

Statistical analysis was performed using the General Linear Models procedure (GLM) of SAS ${ }^{\circledR}$ (SAS Institute 1998) according to the following general model:

$$
Y i j k=\mu+\alpha_{i}+\beta_{j}+(\alpha \beta)_{i j}+\delta_{i j}
$$

where: Yijk was the observed dependent variable; $\mu$-overall mean; $\alpha_{i}-$ effect of cereal; $\beta_{\mathrm{j}}$ - effect of enzyme; $(\alpha \beta)_{\mathrm{ij}}$ - interaction between cereal and enzyme; $\delta_{\mathrm{ij}}$ - random error.

\section{RESULTS}

Cereals with hulls contained more total NSPs, but less soluble NSPs than their hulless counterparts (Table 2). Arabinoxylans predominated among the soluble NSPs of rye, while barley and oat, both with hulls and hulless, contained 5-6 
TABLE 2

Carbohydrate fractions ( $\mathrm{g} \mathrm{kg}^{-1}$ dry matter) and in vitro viscosity (mPas $\left.\cdot \mathrm{s}\right)$ of the cereals

\begin{tabular}{lrrrrr}
\hline Carbohydrate fractions & Barley & $\begin{array}{r}\text { Hulless } \\
\text { barley }\end{array}$ & Oat & $\begin{array}{r}\text { Naked } \\
\text { oat }\end{array}$ & Rye \\
\hline Starch & 633.60 & 615.59 & 554.03 & 611.37 & 612.09 \\
Sugars & 51.83 & 44.38 & 49.09 & 32.27 & 90.05 \\
Insoluble NSP & 94.52 & 72.49 & 138.83 & 41.93 & 84.89 \\
Soluble NSP & 42.55 & 48.60 & 27.65 & 46.90 & 39.73 \\
Total NSP & 137.08 & 121.08 & 166.48 & 88.83 & 124.62 \\
Insoluble arabinoxylans & 68.88 & 52.18 & 104.35 & 24.73 & 58.96 \\
Soluble arabinoxylans & 6.89 & 8.67 & 3.91 & 5.56 & 24.73 \\
Total arabinoxylans & 75.99 & 60.85 & 108.26 & 30.29 & 83.58 \\
Insoluble glucans & 21.12 & 16.89 & 29.55 & 13.56 & 21.73 \\
Soluble glucans & 35.30 & 39.02 & 23.34 & 40.48 & 13.48 \\
Total glucans & 56.42 & 55.91 & 52.89 & 54.04 & 35.20 \\
Total dietary fibre & 172.08 & 130.08 & 232.48 & 120.83 & 145.62 \\
& & & & & \\
In vitro viscosity & & & & & \\
$\quad$ WEV & 2.86 & 1.45 & 2.86 & 2.14 & 7.16 \\
$\quad$ AEV & 5.76 & 2.25 & 4.5 & 2.14 & 2.45 \\
\hline
\end{tabular}

WEV - water extract viscosity, AEV - acid extract viscosity

times more soluble glucans than arabinoxylans. In vitro WEV was highest in rye followed by barley and oat, AEV was highest in barley and oat, lower and similar to rye in hulless barley and naked oat. In vitro viscosity differed between water and acid extracts. In barley and oat, higher values were obtained for acid extracts, whereas in rye, for water extracts. Cereals were the main source of the carbohydrates in all of the diets (Table 1).

In the first two weeks of the experiment only the type of cereal in the diet had a significant effect on $\mathrm{BWG}$ values $(\mathrm{P}<0.05)$. In the grower period, enzyme supplementation as well as the cereal type significantly affected BWG $(\mathrm{P}<0.05)$. The highest improvement in BWG values after enzyme supplementation was recorded in birds fed diets containing rye, oats and naked oats $(\mathrm{P}<0.05)$ throughout the whole experiment (Table 3 ). FCR values were not significantly affected by enzyme supplementation in the starter period. However, with the exception of hulless barley, lower FCR values were observed in all enzymesupplemented diets. In the grower period, enzyme supplementation positively affected FCR values $(\mathrm{P}<0.05)$. Considering the entire experiment, enzyme supplementation had a positive effect on FCR values $(\mathrm{P}<0.05)$ but significant improvement was recorded only in rye and naked oat diets. Mortality in all treatments was zero. 
畄

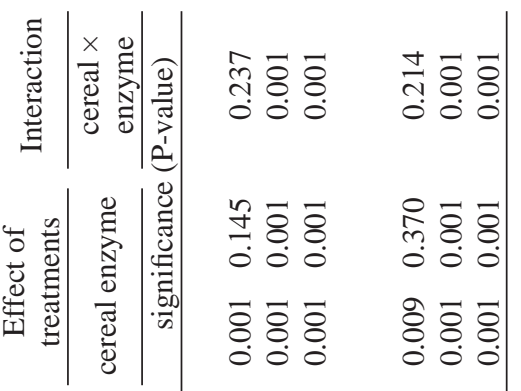

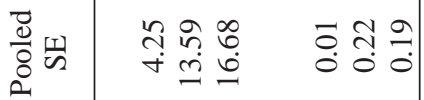

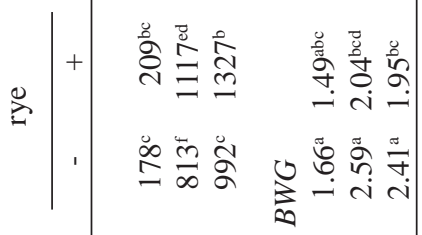

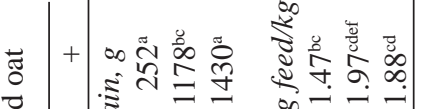

:

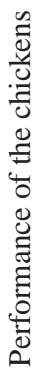

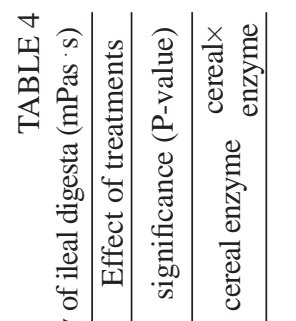

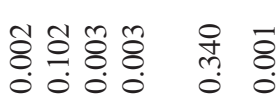

형ㅎㅇ요용

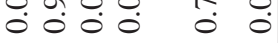

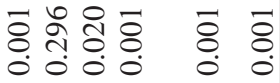

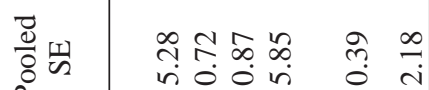

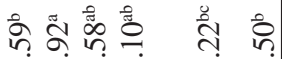

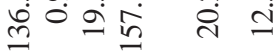

تัँ

হं

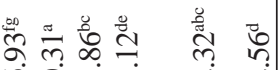

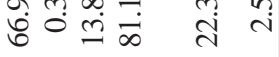

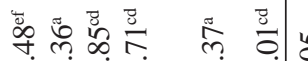
จं

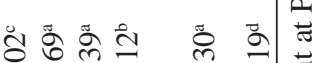
ปั่

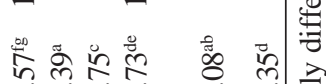
অ बे + +

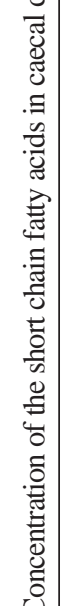
के लंख ते

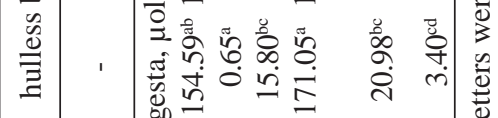

- 1 .

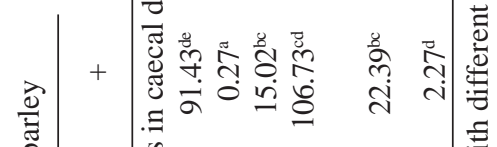

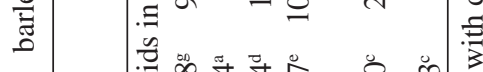

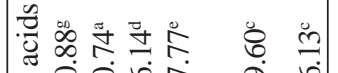
绾宁命

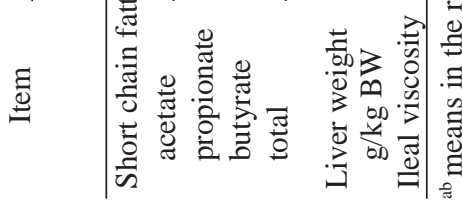


Ileal viscosity depended on type of cereal, being the highest in groups fed rye diets, lowest in the groups fed oat diets. Supplementation with exogenous enzymes lowered intestinal viscosity, however, only in groups fed the rye and barley diets did it differ significantly $(\mathrm{P}<0.05)$ from non-supplemented groups (Table 4).

The type of cereal as well as supplementation with exogenous enzymes significantly influenced the concentration of acetate and sum of SCFA in the caeca $(\mathrm{P}<0.05)$. In all groups, with the exception of naked oat, the total concentrations of SCFA and acetate increased after the addition of enzymes to the diet (Table 4). Following enzyme supplementation, the butyrate concentration was higher in comparison with unsupplemented groups, except in the group fed the diet with hulless barley, while it had no significant effect on liveweight.

\section{DISCUSSION}

It is well documented that supplementation of diets based on cereals having high levels of viscous components (e.g., rye) with microbial enzyme preparations improves the performance of broilers (Steenfeldt et al., 1998; Bergh et al., 1999; Lázaro et al., 2003). This view is supported by the results of the present experiment. Our results agree well with the findings of Lázaro et al. (2003), that the presence of specific fractions of soluble NSPs (i.e. soluble arabinoxylans or/and $\beta$-glucans) rather than the total amount of soluble NSPs in a diet causes a high viscosity of ileal chyme. Reduction of intestinal chyme viscosity is the main function of exogenous enzymes counteracting the antinutritive effects of soluble NSP. Many authors (Bergh et al., 1999; Silva and Smithard, 2002; Lázaro et al., 2003) explain the beneficial role of microbial enzyme preparations by their action in the ileum. According to Bedford and Apajalahti (2001), the action of enzymes may be described in terms of their ileal and caecal phases. During the ileal phase, enzymes prevent the formation of viscous chyme, whereas during the caecal phase, NSP degradation products, like xylose and xylo-oligomers, are fermented by caecal microbes, thus stimulating the production of SCFA. In the presented study the concentrations of acetate, butyrate and total SCFA in caecal contents were affected by enzyme supplementation, in most cases the concentrations of this SCFA increased. This is in agreement with the results reported by Jamroz et al. (1998). In contrast, Lázaro et al. (2003), feeding broiler chickens with rye diets containing different amounts of enzyme preparations, did not record a significant increase of SCFA concentration in caecal digesta.

Our results indicate that a high concentration of total dietary fibre in the diet was not necessarily connected with increased fermentation in the caeca. Fermentation is more dependent on ileal viscosity, which plays a major role in the amount and type of the materials that enter the caeca (Lázaro et al., 2003). Regardless of 
the type and amount of NSPs in the broiler diets, SCFA concentrations may rise in the caecal content after enzyme addition, when more NSPs reach the caeca, which may support Bedford and Apajalahti's (2001) thesis about the two stages of enzyme action. It is interesting to note that in all of the treatments, apart from hulless barley, the addition of enzymes led to higher concentrations of butyrate. In humans, butyrate is one of the most important sources of energy for colonocytes (Roediger, 1995) and stimulates water and sodium absorption (Cherbut et al., 1997). It may be suggested that when assessing the effects of the dietary NSP on fermentation processes in the caeca, a closer look should be taken at the material that effectively enters this region, i.e. which is not only present in the diet, but is also available for microbial degradation in the caeca. The butyrogenic effect of microbial enzyme supplementation and its correlation, if any, with benefits found in humans would be worth investigating.

Jamroz et al. (2002) reported that in chickens, ducks, and geese fed diets containing $40 \%$ barley, fermentation of NSP in the entire gastrointestinal tract contributed from 2.7 to $3.2 \mathrm{~kJ}$ ME per g of feed. The potential energy supply from microbial NSP degradation products is rather small in comparison with total requirements of broiler chickens for energy, but this may be more important for gut epithelial cells (Roediger, 1995). It seems that the better performance of broiler chickens after addition of enzyme preparations to the diet may be due in part to the so-called caecal phase. However, SCFA can also inhibit the growth of some pathogenic microbes (Józefiak et al., 2004), and this second goal could be even more important. In the present experiment, caecal microflora populations, as well as SCFA concentrations may be affected by the salinomycin present in diets. Salinomycin was added as an anticocccidial agent, however Engberg et al. (2000) proved that it also depressed the growth of pathogenic bacteria and improved the performance of broilers.

The major site of SCFA metabolism is the liver, where propionic and butyric acids are almost entirely metabolized. In rats, SCFA concentrations in the portal vein were closely dependent on the inclusion of fermentable carbohydrates into the diet (Demigné et al., 1986). Liver size may depend on the GIT microflora and/or its fermentation end products. Wostmann (1981) reported that the livers of germ-free rodents were smaller than in comparable conventional animals. Brenes et al. (1993) showed that enzyme supplementation of wheat- and barleybased diets caused a reduction of liver weight in broiler chickens by $8 \%$, while Çiftci et al. (2003) recorded increased liver weight after enzyme supplementation in laying hens fed diets based on triticale alone or combined with wheat or maize. In the present study, enzyme supplementation did not affect liver weight. 


\section{CONCLUSIONS}

Ileal viscosity depends more on the physico-chemical properties of dietary fibre fractions than on the level of total or soluble NSP in the diet. Enzyme supplementation may increase the concentration of short-chain fatty acids in the caeca, and may improve the performance of broiler chickens.

\section{REFERENCES}

AOAC, 1990. Association of Official Analytical Chemists, Official Methods of Analysis. 15th Edition. Arlington, VA

Bach Knudsen K.E., 1997. Carbohydrate and lignin contents of plant materials used in animal feeding. Anim. Feed. Sci. Tech. 67, 319-338

Bedford M.R., Apajalahti J., 2001. Microbial interactions in response to exogenouse enzyme utilization. In: M.R. Bedford, G.G. Partrige (Editors). Enzymes in Farm Animal Nutrition. CABI Publishing, pp. 299-314

Bergh M.O., Razdan A., Åman P., 1999. Nutritional influence of broiler chicken diets based on covered normal, waxy and high amylose barleys with or without enzyme supplementation. Anim. Feed Sci. Tech. 78, 215-226

Boros D., Marquardt R.R., Slominski B.A., Guenter W., 1993. Extract viscosity as an indirect assay for water-soluble pentosan content in rye. Cereal Chem. 70, 575-580

Brenes A., Smith J., Guenter W., Marquardt R.R., 1993. Effect of enzyme supplementation on the performance and digestive tract size of broiler chickens fed wheat- and barley-based diets. Poultry Sci. 72, 1731-1739

Çiftci İ., Yenice E., Eleroglu H., 2003. Use of triticale alone and in combination with wheat or maize: effects of diet type and enzyme supplementation on hen performance, egg quality, organ weights, intestinal viscosity and digestive system characteristics. Anim. Feed Sci. Tech. 105, 149-161

Cherbut C., Aubè A.C., Blottière H.M., Galmiche J.P., 1997. Effects of short-chain fatty acids on gastrointestinal motility. Scand. J. Gastroenterol. 32, Suppl. 222, 58-61

Choct M., Hughes R.J., Bedford M.R., 1999. Effects of a xylanase on individual bird variation, starch digestion throughout the intestine, and ileal and cecal volatile fatty acid production in chickens fed wheat. Brit. Poultry Sci. 40, 419-422

Demigné C., Yacoub C., Rémésy C., 1986. Effects of absorption of large amounts of volatile fatty acids on rat liver metabolism. J. Nutr. 116, 77-86

Engberg R.M., Hedemann M.S., Leser T.D., Jensen B.B., 2000. Effect of zinc bacitracin and salinomycin on intestinal microflora and performance of broilers. Poultry Sci. 79, 1311-1319

Englyst H.H., Cummings J.H., 1984. Simplified method for the measurement of total non-starch polysaccharides by gas-liquid chromatography of constituent sugars as alditiol acetates. Analyst 109, 937-942

Jamroz D., Jakobsen K., Bach Knudsen K.E., Wilczkiewicz A., Orda J., 2002. Digestibility and energy value of the non-starch polysaccharides in young chickens, ducks and geese, fed diets containing high amounts of barley. Comp. Biochem. Physiol. Pt. A 131, 657-668

Jamroz D., Wiliczkiewicz A., Skorupińska J., 1998. Fermentation and apparent digestion of the structural carbohydrates in chicks, ducks and geese fed triticale mixuters supplemented with enzymes (in German). J. Anim. Physiol. Anim. Nutr. 79, 1-17 
Jensen M.T., Cox R.P., Jensen B.B., 1995. Microbial production of skatolein in the hindgut of pigs given different diets and its relation to skatole deposition in backfat. J. Anim. Sci. 61, 293-304

Józefiak D., Rutkowski A., Martin S.A., 2004. Carbohydrate fermentation in the avian ceca-A review. Anim. Feed. Sci. Tech. 113, 1-15

Lázaro R., Garcia M., Medel P., Mateos G.G., 2003. Influence of enzymes on performance and digestive parameters of broilers fed rye-based diets. Poultry Sci. 82, 132-140

Roediger W.E.W., 1995. The place of short chain fatty acids in colonocyte metabolism in health and ulcerative colitis: the impaired colonocyte barrier. In: J.H. Cummings, J.L. Rombeau, T. Sakata (Editors). Physiological and Clinical Aspects of Short-Chain Fatty Acids. Cambridge University Press, Cambridge, pp. 337-351

Silva S.S.P., Smithard R.R., 2002. Effect of enzyme supplementation of a rye-based diet on xylanase activity in the small intestine of broilers, on intestinal crypt proliferation and nutrient digestibility and growth performance of the birds. Brit. Poultry Sci. 43, 274-282

Steenfeldt S., Müllertz A., Fris Jensen J., 1998. Enzyme supplementation of wheat based diets for broilers. 1. Effect on growth performance and intestinal viscosity. Anim. Feed. Sci. Tech. 75, $27-43$

SAS, 1996. SAS®/STAT User`s Guide: Statistics Cary, NC, SAS Institute Inc. (USA)

Wostman B.S., 1981. The germfree animal in nutritional studies. In: W.J. Darby, H.P. Broquist, R.E. Olson (Editors). Annual Reviews of Nutrition Vol. 1. Palo Alto, Annual Reviews Inc., pp. 257-279

\section{STRESZCZENIE}

\section{Wpływ frakcji włókna pokarmowego różnych gatunków zbóż i dodatku preparatów en- zymatycznych na wyniki odchowu, lepkość treści jelitowej i stężenie krótkołańcuchowych kwasów tłuszczowych w treści jelit ślepych kurcząt brojlerów}

Przeprowadzono doświadczenie na 960 jednodniowych kogutkach brojlerach, podzielonych na 10 grup, z których każda składała się z 12 (powtórzeń) klatek po 8 ptaków w klatce. Kurczętom podawano przez 5 tygodni diety zawierające różne gatunki zbóż (jęczmień, jęczmień nieoplewiony, owies, owies nagi lub żyto), jako główne źródło węglowodanów. Diety przygotowano bez lub z dodatkiem preparatów enzymatycznych Avizyme. We wszystkich grupach dodatek preparatu enzymatycznego poprawił wykorzystanie paszy, jednak tylko w grupach zawierających nagi owies i żyto różnice były istotne statystycznie $(\mathrm{P} \leq 0,05)$; podobna zależność wystąpiła w przypadku końcowej masy ciała. Lepkość treści jelita cienkiego była niższa we wszystkich grupach, w których zastosowano dodatek preparatów enzymatycznych. W treści jelit ślepych grup otrzymujących diety z dodatkiem preparatów enzymatycznych, z wyjątkiem kurcząt otrzymujących diety zawierające owies nagi, zwiększyło się stężenie krótkołańcuchowych kwasów tłuszczowych. Wyniki doświadczenia wskazują, że nie całkowita zawartość włókna pokarmowego w diecie, lecz rodzaj węglowodanów nieskrobiowych oraz uzupełnienie diety enzymami paszowymi wpływa na lepkość treści jelitowej oraz wyniki odchowu kurcząt broilerów. 